\title{
Correction to: Who Is the Prophet? Jackie Robinson, Branch Rickey, and the Integration of Baseball
}

\author{
Rebecca Alpert
}

\section{Correction to:}

Chapter 3 in: T. Shoemaker (ed.), The Prophetic Dimension of Sport, Briefs in Religion and Sport, https://doi.org/10.1007/978-3-030-02293-8_3

The original version of the book was inadvertently published with incorrect information in chapter 3; the correction is given below.

- Page 20, text in the third paragraph second line from the base, 'often termed an "uppity Negro" by writers and fans' has been deleted.

- Page 20, text in second paragraph fourth line from the base after the text 'fans and Players'

'for development of this idea see Nanko-Fernández, "Turning Those Others' Cheeks: Racial Martyrdom and the Re-Integration of Major League Baseball" in Gods, Games and Globalization, forthcoming' has been added. 